\title{
Work Habit, Risk-Taking Ability, and Entreprenuerial Success
}

\author{
Don- Baridam Letam (M.sc. B.sc). \\ Department of Management, Faculty of Management Sciences, Rivers State University of Science and \\ Technology
}

\begin{abstract}
This study examines the relationship between work habit, risk-taking ability and entrepreneurial success secret of entrepreneurs' success. The respondents were 120 entrepreneurs, all members of petroleum technological Association of Nigeria (PETAN), an association founded with the effective of domesticating oil related technologies in Nigeria. The multiple regression analysis was used to measure the relationships between the dependent and independent variables.

Results indicated that there is a positive significant relationship, at the .05 level of significance, between the class arid covariate variables, it is reasonable to conclude that there is a positive relationship between these variables and entrepreneurial success.
\end{abstract}

Keywords: Work Habit, Ability, Risk-Taking, Entreprenuerial Success

\section{Introduction}

The attempt to discover the secret of entrepreneur's success has preoccupied researchers and analysts from a variety of disciplines both in the social sciences and in the humanities in recent years. Biographies of successful entrepreneurs and businessmen, for example, reflect the tendency of the subjects of such studies to explain their success in terms of simple virtues of thrift, hard work, and clean living.

As an alternative to the biographical models are those studies that turn the entrepreneur into a superman manipulating the complexities of an uncertain world with sure and omnipotent touch (Gasse, 1983). Thus, emerges the notion of the 'genuine entrepreneur' whose success is in large measure caused by his unswerving dedication to setting high goals and reaching for them.

While there is general consensus that the most unique aspect of entrepreneurs is that they start new enterprise, there is less than unanimous agreement as to what factors are most important to their success and failure.

However, one thing that seems to emerge from all these debates is that the generally accepted prerequisites to success in any business are the work habit and the risk taking ability of the entrepreneur. The purpose of this study is to identify some variables that are relevant to the work habit and risk-taking ability of the entrepreneur, and to measure the extent to which these variables are likely to contribute to success or failure in entrepreneurship. Given these objectives, the exact research questions are:

1. Is there a relationship between work habit and entrepreneurial success?

2. Is there a relationship between entrepreneurial success and risk taking ability?

Work Habit And Entrepreneurial Success

\section{Literature Review}

Entrepreneurial activity is a precarious and uncertain endeavour. It is difficult and frustrating. As Perrow (1967:195-196) posits, it is a non-routine activity in that almost by definition, it is oriented toward ends which entail unanticipated problems of procedure and which do not provide clear guidance for resolving these problems.

Although there are other factors which determine entrepreneur's output; his every day work habits are very important. As individual work habits vary, so does the variation in the entrepreneur's ability to cope with difficulties and frustrations that often characterize entrepreneurship. Stinchombe (1966, cited in Hargens, 1978:98) has argued that since entrepreneurial activities concepts of self are intimately related to their work, and since their work is very non-routine, difficulties in entrepreneurial work are likely to result in loss of personal motivation to persist in its performance. Under these conditions, Stinchombe continue, the presence of eternal motivating forces such as commitment to "rather forbidding, non-indulgent figures', or to have work completed by certain time, may be able to provide enough to motivate the individual through periods difficulty.

Referring to the work habit of a typical entrepreneur of a less developed country, Broehl (1978) contends that the entrepreneurs at any given moment is playing many different roles; a part of a family, a religious sect, a political party leader, a kinship coup, and so on (Broehl, 1978:258 cited in Rothenberg 1958). It is reasonable to assure that there is a relationship between the time spent on entrepreneurial activity and entrepreneurial success. 
Routine forms of work output, according to Hargens 1978:99) are positively related to time spent on work, but insofar as entrepreneurial activity is non-routine, this relationship should be attenuated if not absent. Simon (1974:329 - 330) posits that famous people tend to work long hours, this finding consistent with the claims that entrepreneurial success is a function of time spent on entrepreneurial activities.

Clinton believes that seasoned entrepreneurs like deals that involve no-money stake but special knowledge and special friendship. He posits that:

Entrepreneurs continually uncover, nurture, and use an ever-broadening circle of people 'in the know' and 'the right places'. They count on these contacts and connections to cut corners. They know that the 'right' people can provide entry pave the way for acceptance, and enhance image and credibility. They can also provide information and support, help avoid 'time-consuming activities' and help locate resources needed (or entrepreneurial success (Mitton, 1982:80)

''Individuals who spent a great deal of time on entrepreneurial activity, the author 'continued, are not necessarily likely to be successful". It would be necessary to ask at this juncture: to what extent is entrepreneurial success a function of time spent on entrepreneurial activity? According to Lodahi and Gordon (1 972:70), the most highly developed fields have the most efficient communication processes to spend development further. This situation could generate success with little time spent on entrepreneurial activities. The structure of entrepreneurship is non-routine and less predictable and it is difficult to generalize the work habit that leads to success. Ability to succeed may not necessarily depend among other things, on the everyday work habits of the entrepreneur.

\section{Risk Taking Ability And Entrepreneurial Success}

A risk situation occurs when you are required to make a choice between two or more alternatives whose potential outcomes are not known and must be subjectively evaluated (Meredith, Nelson, Nook, I 982:25). People are afraid to take risk because they want to be safe and avoid failure. But the entrepreneurs are constantly involved in risk-taking because they want to be successful.

Considering a risk-taking situation in business especially in Nigerian environment, Broehl (1964) asserts that entrepreneurs sometimes consult horoscope before business dealings. He contends that such fatalistic nature of decision-making tool as guarantee against risk, could inevitably lead to a gambling mentality. Beals (1974) supports this argument concerning the entrepreneurs in less developed countries. He concluded that: Entrepreneurs may have a keen sense of risk-taking in their various risk taken in their various business dealing yet many of their decisions are infiltrated by superstition and guessing; entrepreneur tend to swing widely between gambling and risk aversion. The result is often pervasive mistrust, fatalism and rage at the implacability of fate (Beats, 1974:262).

Nwachukwu (1990:202), however, believe that a typical entrepreneur faces risk in all his activities irrespective of the extensive precautions that he would like to take. On the contrary, Meredith, Nelson, Neck (1982) identified the sharing of risk in an organization as a crucial factor for entrepreneurial success. The determination of risk taking ability to entrepreneurial success is therefore a function of the willingness of the entrepreneur to risk delegating authority and responsibility to people in the organization.

\section{The proposition is summarized as follows:}

Risk-taking is especially important in delegating authority and responsibility to low staff allowing others to share your power is a characteristic of growth-oriented successful entrepreneurs. The more you can delegate power successfully the more you will have to deal with those activities having the greatest impact on your organization's future successes (Meredith, Nelson, Neck,1982: 31).

Contrary to this view, Sexton and Bowman (1983) argue that risk taking ability may not distinguish entrepreneurs or contribute to the decision to enter entrepreneurial activities. A number of caveats accompany this statement. They contend that risk-taking ability cannot easily be measured as it has several dimensions. That although much of the risk-taking ability that one has is predisposed, there are environmental factors that can alter one's perception of risk situation. For example, the amount of uncertainty one perceives in a decisionmaking environment affects the degree of risk the decision-maker will take. Second, it should not be accepted that the different tests designed to measure the same characteristic actually measuring in the same way at the same level of awareness.

Aighbee (1971) found out that people classified as high risk-takers anticipate taking higher risk in complex decision-making task than people classified as low risk-takers takers .the low groups did not differ in actual behaviour on the task. Subject may perceive themselves as being "risky" when, in fact they are not. The above discussions suggest that risk-taking ability is a factor in entrepreneurial succe 


\section{Methodology}

Respondents: The respondents were 120 entrepreneurs, all members of petroleum technological Association of Nigeria (PETAN), an association founded with the effective of domesticating oil related technologies in Nigeria.

The 120 entrepreneurs were classified based on their financial returns for the firms within the last three years. This is a method used by Duchesneau and Gartner (1987) in their work "Profile of New Venture Success and Failure'. The successful firms realized a net profit of over N200, 000 annually. For the unsuccessful firms, entrepreneurs have not completely discontinued operation, but they have provided no profit and directors salary since January 1, 1993. No firm older than 10 years were included in the study.

\subsection{Data collection:}

Questionnaires were distributed to 120 entrepreneurs owner managers of the Petroleum Technological Association of Nigeria. One hundred and two usable questionnaires provided the data base ( 85 per cent response rate).

\subsection{Measures:}

Dependent Variable: The specific dependent variable to which this study is addressed is entrepreneurial success. This was operational led as the ability of the Owner manager to start, nurture, and effectively manage a company, whose success determinant s calculated from the average profit of the firm in 3 years proceeding the survey period. An average profit of N200,000 per annum was considered appropriate for the measurement of entrepreneurial success. This definition is consistent with the method used by Duchesneau and Gartner (1987) in their work "Profile of New Venture Success and Failure".

\subsection{Independent Variables:}

Work habit is the consideration of the approximate proportion of working time spent entrepreneurial activity. This was measured using a self-rating scale developed by

Sponsor and Mansfield (1986). The rating scale consists of the Following 5 statements

$\checkmark \quad$ I give much effort to my work.

$\checkmark \quad$ I work long hours and make personal sacrifices to complete jobs on time.

$\checkmark$ I do whatever it takes to complete a job.

$\checkmark$ When working on a project for someone, I ask many questions to be sure I understand what the person wants.

$\checkmark \quad$ I do not let my work interfere with my family or personal life.

Risk Taking Ability - This was measured using the risk-taking chart developed by Meredith, Nelson and Neck (1982). The research statement centers on the extent to which the entrepreneur allows situations such as staff freedom, permits staff to take risk, and delegate's authority in his firm.

The multiple regression analysis was used to measure the relationships between the dependent and independent variables.

\section{Results And Discussion}

Relationship Between Work habit (WI I) arid Entrepreneurial Success (ES )

Our multivariate regression analysis shows a positive and non significant relationship between work habit and entrepreneurial success.

$$
\begin{aligned}
\mathrm{ES}= & 43+127 \mathrm{WH} \\
& (\mathrm{t}=499) \\
& \left(\mathrm{R}^{2}=48\right)
\end{aligned}
$$

Possible explanation for this result can be advanced. First, success in business in most developing countries, Nigeria inclusive, may not to some extent depend on work habit but having the right connection. Entrepreneurial success for the respondents surveyed in this study depends, among other things, on the number and amount of contracts received; Studies have shown that very open contracts are awarded to those that have the right connection and not their qualifications(See Baridam, 1993, lyanda 1993).

Therefore, an entrepreneur can achieve a reasonable degree of success (measured in terms of annual profit) without necessarily having the right work habit. Second the structure of entrepreneurial activity is non routine and less predictable. This is because of the dynamic nature of the business environment. This property of the business environment may likely impede entrepreneurial success. 


\subsection{Risk Taking Ability (RTA) and Entrepreneurial Success}

The result of our analysis shows that there is positive and significant relationship between risk taking ability and entrepreneurial success.

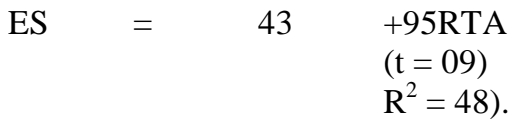

In theory, properly articulated and well channeled risk-taking potentials is a linear function of entrepreneurial success. In financial theory there is a trade-off between risk and return (profit) such that the higher the risk taken by the investor, the higher the returns expected in the activity (Pandey, 1982). Nwachukwu (1990:202) believes that the entrepreneur is a risk-taker, and is plagued by risky situations in all his activities irrespective of the extensive precautions he would like to take. Our median score confirms these tendencies of risk taking abilities among the respondents. However, our concern is, why is this observed characteristics not significant at the 05 significant level?

Perhaps, it is reasonable to assume that this positive factor of risk-taking is not well directed, harnessed and utilized by the entrepreneurs studied.

\section{Conclusion}

This work has examined the relationship between work habit, risk-taking ability and entrepreneurial success. Although our data tailed to show a significant relationship, at the .05 level of significance, between the class arid covariate variables, it is reasonable to conclude that there is a positive relationship between these variables and entrepreneurial success.

We should, however, add that despite the relevance and the appropriateness of this study at this time in the development of entrepreneurship in Nigeria, the sample size limits the extent to which we can make broad generalizations from the findings.

\section{References}

[1]. Ahighbee K. (1971) "The Expression of Walter Mitty-ness in Actual Behaviour" Journal of Personality and Social Psychology 20 (December), p. 416.

[2]. Baridam D.M. (1993) Management and Organization Theory, Port Harcourt. Pam Unique Publishers

[3]. Beals, A (197'l) Village life in South India Chicago, Aldine,

[4]. Brool, W.G (1978) The Village Entrepreneur. Cambridge, Harvard University.

[5]. Duchesneau D.A. and Gartner W.B. (1987) Profile of New Venture Success and Failure in an Emerging Industry Fort Lauderdale Florida, Nova University.

[6]. Gasse, Y. (1983) 'Identification and Development of Potential Entrepreneurs' Proceedings of 10th International small Business Congress, edited by Ng Cheng Swong, pp. 1-7 (September) Singapore.

[7]. Hargen, L.0. (1978) "Relationship Between Work Habit, Research Technologies, and Eminence in Science" Sociology of Work and Occupation Vol 5

[8]. Lodahi, J.B. and Gordon, G. (1972). "The Structure of Scientific Fields arid the Functioning of University Graduate Departments" American Sociological Review VOL 37, pp. 57-72

[9]. L lyanda, A. (1993) “The Travails of Small-Scale Investors in Developing Economy’ Nigerian Guardian Publication, Lagos.

[10]. Meredith, G, Nelson H, Hook, R. (1982) The Practice of Entrepreneurship International Labour of Fc', Geneva.

[11]. Mitton R. (1982) Entrepreneurial Careers: A study of the Careers Pathways Pursued by Babson Entrepreneurs. Unpublished manuscript Board of Research, Babson College.

[12]. Nwachukwu, CC. (1990) The Practice of Entrepreneurship in Nigeria African Fop Pub she rs

[13]. Pandey .J. (1982) "I OCUS of Control nod Achiovornonl at Entrepro; ro 1 ' lain ii if at Occupational Psychology 52 No. 2.

[14]. Perrow, C. (1967) “A Framework for the Comparative Analysis of Organization” American Sociological Review Vol 32. pp. 1 94-208.

[15]. Simon, R. (1974) 'The Work Habit of Eminent Scientists" Sociology of Work and Occupations 327-335

[16]. Sponsor, L.M. and Mansfield R. (1989)The identification and Assessment of Competencies and Other Characteristics of Entrepreneurs in Developing Countries Boston: McBer and Company.

[17]. Stincombe, A.L. (1966) "On getting Hung - up and Other Assorted illness' Quoted ri Lowell L. 